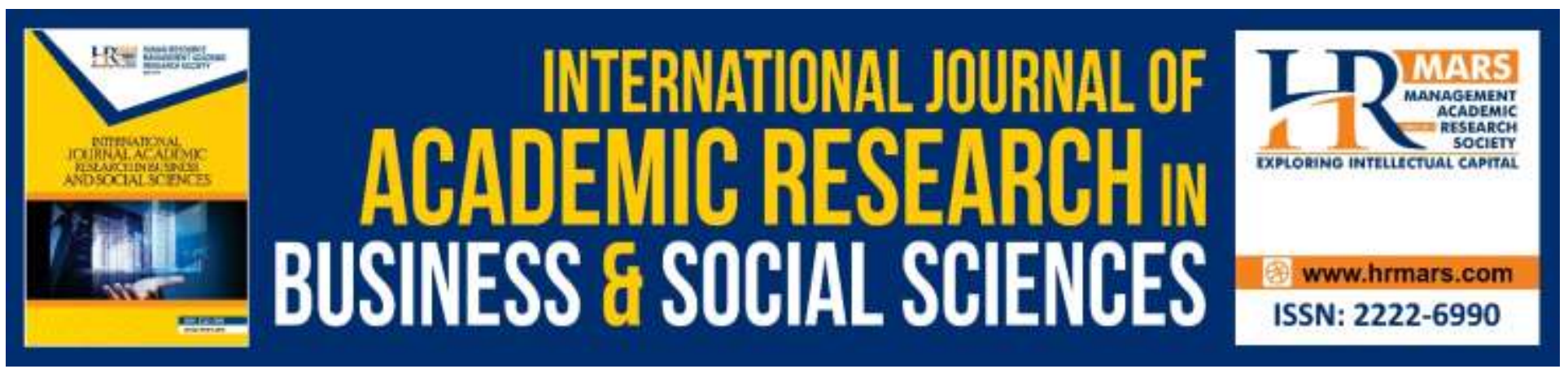

\title{
The Effects of Boko Haram Insurgency on The Internally Displaced Children in Nigeria
}

Adekunle Daoud Balogun, Mohammed Afandi Bin Salleh and Abdullahi
Ayoade Ahmad

To Link this Article: http://dx.doi.org/10.6007/IJARBSS/v10-i2/7010

DOI:10.6007/IJARBSS/v10-i2/7010

Received: 11 January 2020, Revised: 01 February 2020, Accepted: 12 February 2020

Published Online: 27 February 2020

In-Text Citation: (Balogun et al., 2020)

To Cite this Article: Balogun, A. D., Salleh, M. A. Bin, \& Ahmad, A. A. (2020). The Effects of Boko Haram Insurgency on The Internally Displaced Children in Nigeria. International Journal of Academic Research in Business and Social Sciences, 10(2), 786-813.

\section{Copyright: (C) 2020 The Author(s)}

Published by Human Resource Management Academic Research Society (www.hrmars.com)

This article is published under the Creative Commons Attribution (CC BY 4.0) license. Anyone may reproduce, distribute, translate and create derivative works of this article (for both commercial and non-commercial purposes), subject to full attribution to the original publication and authors. The full terms of this license may be seen

at: http://creativecommons.org/licences/by/4.0/legalcode

\section{Vol. 10, No. 2, 2020, Pg. 786 - 813}

Full Terms \& Conditions of access and use can be found at http://hrmars.com/index.php/pages/detail/publication-ethics 


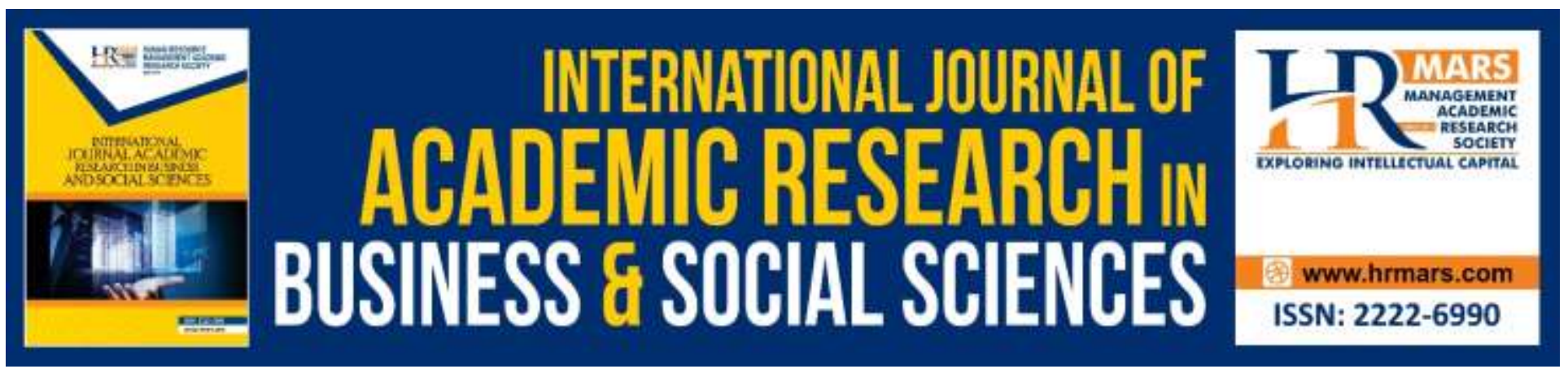

\title{
The Effects of Boko Haram Insurgency on The Internally Displaced Children in Nigeria
}

\author{
Adekunle Daoud Balogun, Mohammed Afandi Bin Salleh and \\ Abdullahi Ayoade Ahmad
}

Faculty of Law and International Relations, Universiti Sultan Zainal Abidin (UniSZA) Terengganu Malaysia

\begin{abstract}
Wars and conflicts have no other reward that could benefit human beings than widespread devastation and landmark loss of lives. There have been studies carried out on the reasons that cause terroristic acts and the devastated effects of the of the terroristic activities of the Boko Haram Nigeria however; its effects on displaced children have not been fully addressed. The study investigates the legal rights and the future of the displaced children under humanitarian activities. The kidnapping of innocent children as spoils of war while they are being forced to act as child soldiers, suicide bombers or otherwise invariably changed their future dreamed ambition in life. Therefore, the study argues the need for a provision of future-promising, effective assistance that could secure them a better alternative ambition that streamlines and sustains the future of the internally displaced children and those children freed from captivity. The research builds its premise on theoretical framework of aggression. The study found that public sector corruption and saboteurs' activities are undermining the effort of the government to implement sustainable policy for the children future. There are other factors responsible for broaden insurgents' violent activities and the corresponding effects. The refusal of the America to sell arms needed to fight the Boko Haram is another major factor that not only prolong the war but give advantage the insurgent group. The study adopts qualitative method via secondary data such as academic published journal articles, books, government websites, newspapers and magazines and reliable online information. The study applied descriptive and analytical method of analysis for its investigation. This research recommends the appropriate strategies for fighting corruption, handling internal displaced children and prevent future insurgency. The significance is of huge importance to the policymakers and other relevant stakeholders such as, calling for pragmatic use of the information intelligence, train more army and police recruits and devise strategies for future study on prevention of children from being abused by the insurgents and the government officials.
\end{abstract}

Keywords: Boko Haram, Kidnaping, IDPs Children, Humanitarian Prevention 


\section{Introduction}

Nigeria is located in the West African region, bounded by the Republic of Benin on the west, the Republic of Niger on the north, the Republic of Chad on the Northeast, the Republic of Cameroun on the southeast and the Atlantic Ocean on the southern part. Nigeria has a landmass of $(356,667$ square miles) $(923,768 \mathrm{sq} . \mathrm{km})$ with a coastline on the southern part that measured 530 miles $(853 \mathrm{~km})$ (Briney, 2017). Nigeria is the most populous African country with a population of 182 million (WHO, 2015).

In 1967, Nigeria witnessed a civil war that ravaged the country in 1967-1970, since then, the country has not experienced any internal conflict that claimed more lives like the one perpetrated by the Boko Haram Islamist terroristic insurgency. The group hailed from the North East of Nigeria. It became well known in July 26-29, 2009 when some cyclists who happened to be Boko Haram members did not comply with the law of wearing helmet while riding motorcycle, they defied the regulations of wearing helmet and the arrest of their group members resulted to staging attack on police (Sani, 2012; Khalid, Islam \& Ahmed, 2019). Later, the leader of the group Muhammed Yusuf was apprehended and detained in the police custody but police committed extrajudicial killing against him. They claimed he wanted to escape from the detention cell in July 2009. The group eventually vowed to make a revenge of their leader and of the group members that were killed by the Nigerian security members in 2009.

Boko Haram claimed to be working towards the ambition to govern Nigeria with Islamic Shariah law and the group has blunt disregard for western education. Boko Haram emerged around 2002 as full blown terrorist group. It has taken its terrorist activities in recent times to and across the Nigerian borders to some of the neighboring countries like Niger, Chad, and Cameroun. According to Shuaibu and Salleh (2016); the insurgency has negative effects on six million Nigerians, cost more than 13,000 lives and displaced 300,000 people. The word 'Boko Haram' in literal translation is 'western education is forbidden' the slogan of the group however, the real name in Arabic is Jama'ahal Ahlu al-Sunnah Li al-Da'wahwa al-Jihad.

\section{Areas in Nigeria where Boko Haram was most active}

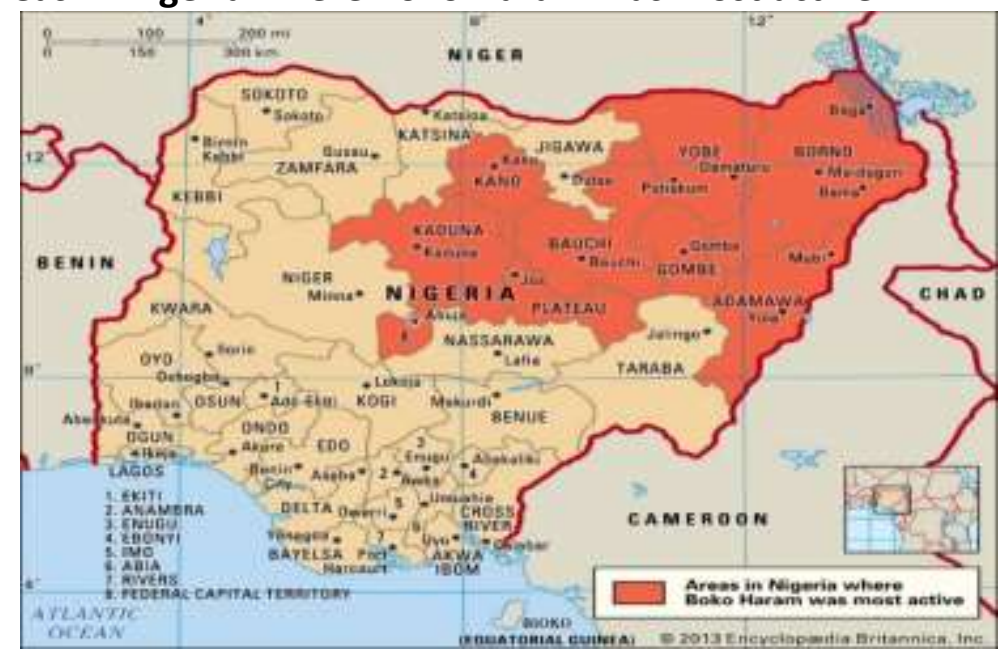

Source: Encyclopedia Britannica (2013). 
INTERNATIONAL JOURNAL OF ACADEMIC RESEARCH IN BUSINESS AND SOCIAL SCIENCES Vol. 10, No. 2, Feb, 2020, E-ISSN: 2222-6990 @ 2020 HRMARS

\section{The Problem Statement of the Study}

The members of the Boko Haram forcibly kidnapped a lot of innocent children and adults while many were killed and some were unaccounted for in Boko Haram terroristic war fought in order to register their grievances against the authorities. The kidnapped children and grown-up people were helplessly subdued and kept in the Boko Haram den. Most of them spent years in captivity while some of them were being used for activities against their will but they were rather served the interests of the militants. For instance, the 287 Chibok Girls' Secondary School students were kidnapped in 2013, only 152 were freed while the rest remained in captivity. The Girls Secondary school student in Dapchi were kidnapped on but the government led by President Buhari rescued all of them except a girl 'Lear' who refused to renounce her Christianity still remained with the Boko Haram. A significant number of people that were not captured by the militant groups were displaced out of the fear of being caught for similar motives. Some were displaced as a result of the demise of their parents, guardians or relatives in their presence when they were being terrorized or attacked at gunpoint. Lack of food security, shelter, and a decent life are among reasons for IDP to take place as they may not survive in their family or rented houses that were already razed or burnt down by the terrorist groups. The government took the responsibility of providing the temporary shelters put up inform of tents or cabins with availability of necessity of life such as clothing, food, water, rest-rooms, security and health centres where the health professionals can attend to the health issues as well as security that would guarantee reoccurrence of the sudden, violent attacks they experienced in the original communities.

Hence, the study observed that most of the studies on the war of terror by the Boko Haram terroristic attacks on the people of the country especially in the Northeast of Nigeria did not addresse the fate of the children caught in the violent attacks as many of them have lost either one or both parents temporarily during displacement or permanently after being attacked by the terrorists at gun points as well as when they were trapped in houses razed with fire.

\section{Literature Review}

General perception shows that the displacement of people mostly happens during the war even though war happens any time in different countries across the world but in different forms and dimensions. For instance, a war between one state and another is identified as a result of forceful intervention or occupation of one's sovereign territory by another such as Palestinian land occupied by the Israel since (1947-48) civil war. This occupation attempt causes violent attacks and hostilities between the people as well as governments of Israel and Palestinian political leaders. War can happen between states and non-state actors such as in the case of the Syrian government and the anti-government rebel groups, such as the state of Iraq and the Islamist state terrorist groups (ISIS), the state of Afghanistan and the Taliban groups.

Wars have erupted between two countries such as Russia and Georgia in 2008, Iraq and Iran from September (1980-1988) or between the USA and Vietnam in (1954-1975). A disagreement between political lords may result to agitation for secession by a region as a result of the feelings for social, political or economic exclusion or differences in religious belief. This development may escalate and finally result in dividing a country into two or more fragments such as in the Republic of Sudan in 
which South Sudan gained independence from Sudan on 9 July 2011 following the outcome of the 2005 Nairobi Agreement that ended Africa's longest-running civil war (BBC, 2018; Alzgool, 2019; Muhammad, Saoula, Issa \& Ahmed, 2019). All these hostilities caused the internal displacement of people including the children who are virtually innocent while living under the care of their affected parents during the time of war. In a similar trend, the Boko Haram's reason for striking and carrying weapon against the legitimate government of Nigeria was not different from ideological differences. The group wages war to govern northern Nigeria with Islamic Shariah law among others while the Republic of Nigeria operates a circular, democratic government.

\section{Characteristics of Internal Displacement}

Persons or groups of people that found themselves under threat deserve prevention of life and property by fleeing the location where they experienced violent attack to a peaceful, temporary or permanent place within the sovereign territory of their country without crossing the country's recognised border are referred to as Internally Displaced Persons." (Guiding Principles, Introduction, para. 2). According to the Handout of the Internal Displacement Monitoring Center (iDMC) under the Refugee Council of Norway, two main important elements must be identified regarding the definition of Internal Displaced People:

Firstly, it must be a coercive or involuntary character of changing location and secondly, such baseshift must be performed in the country of the victims. Internal Displacement of people would take place among a group of people, being expelled by force or threat that becomes a necessity to flee involuntarily. Displacement of people is not always carried out under rush but when people anticipate danger in the nearest future. It sometimes takes place under organized arrangement. The displacement takes place to avoid threat or conflict or danger that may result in the death of people as well as property loss or it takes place to avoid such consequences under anticipation. Secondly, under the humanitarian context, the displacement may not be completed without mentioning the next terminal of such involuntary movement. Displaced people may end up in a temporary shelter that could be a bare land where an individual makes his or her sleeping place or where a government or nongovernmental organization(s) prepares camping tents or temporary cabins for the displaced people to stay with the provision of necessities of life such as food, water and restrooms.

\section{General Causes of Internal Displaced People (IDP)}

Issues of Internal Displacement has been a great global concern since 1990. (iDMC) There are recommendations for the internal displaced persons many that have been argued in few paragraphs below (2013-2019). The Kampala Convention stipulate series of resolutions for national authorities to adopt in guiding the interests of the displaced people such as provision of assistance to the IDP, find the causes, recognized the impact of the civil society and adoption of national legislation in the interest of the IDP. There are series of causes of displacement of people which are similarly applicable to the internal displacement of children in the event of a threat, danger or virtual war on the innocent people in a place at a particular period. The conflict between arms groups and the State or the purpose of being socially excluded or seeking independence, autonomy or when warring factions want to secede from a legitimate authority can pose a threat worth displacement of the people. 
Some conflicts may cause the displacement of people if escalated beyond the exercise of patience and understanding; a kind that may become violent with no regard for human life. This may include sporadic gunshots and physical confrontations. Sometimes, people who may be vulnerable to abuse in most cases are children and women because they are physically incapacitated to confront armed gangs or those who can overpower them during the struggle for survival. In such situations, violation of human rights is imminent against their will; in that case, the internal displacement of people is not negotiable. Natural disasters such as Typhoon, Hurricane, and Flooding of places and residents after heavy rainfall or Fire disaster especially during the winter period may render people homeless hence, displacement takes place. In the event of restructuring a settlement to allow for the construction of modern buildings or mass housing projects to replace slum settlement, hence, displacement of people is a necessity to allow for effective construction as well as to pave the way for the safety of the people's lives.

It is identified that the warring factions do not have much attention and passion for displaced people but rather than capturing as many as possible among them for their agenda. As a result, who are in charge to maintain that security of the IDP? It is understood that in the case of war, violent attack or a conflict between two or more warring factions, the State authority through its disaster respond squad are saddled with the responsibility to arrange for the delivery of necessary materials and its distribution to the IDP. However, the sufferings of the IDP may be serious where the conflicts occur between the State authority and none-state actors or any militant organizations as witnessed in the case of the Islamist State and the State of Iraq. There are reports of Islamist states obstructing the delivery of foods and materials to the internally displaced people in Iraq. However, in the case of Nigeria, the National Emergency Management Agency (NEMA) in collaboration with the National Commission for Refugees, Migrants, and IDPs (NCFRMI) are being responsible for the IDPs inundated with natural disaster or any violent crimes committed against the people in the country such as terroristic acts of Boko Haram and other forms of insurgency.

The study therefore prepares to provide answers to the following objectives.

\section{Objective of the Study}

The study is based on the insurgency of the Boko Haram as experienced in Nigeria for more than a decade and the aftermath of the violent attacks on the people of the concerned states and the communities in Nigeria in general. The study would specifically investigate:

(1) The reason for the activities of the insurgent groups of the Boko Haram in Nigeria.

(2) The Internal Displaced Persons (IDP) and its related effects on the children who found themselves within the circumstances at the (IDP) camp following the crisis caused by the Boko Haram terroristic attacks.

\section{Research Question}

(1) What are the reasons for insurgent activities of the Boko Haram in Nigeria?

(2) What are the related effects on the children who found themselves within the circumstances at the Internally Displaced Persons (IDP) camp following the crisis caused by the Boko Haram terroristic attacks? 
INTERNATIONAL JOURNAL OF ACADEMIC RESEARCH IN BUSINESS AND SOCIAL SCIENCES Vol. 10, No. 2, Feb, 2020, E-ISSN: 2222-6990 @ 2020 HRMARS

\section{Methodology}

The study adopts documentary research method to source secondary data for the study. The adoption of primary data was constrained over the facts that the matters related to insurgency and the controversial issues of corrupt behavior in the IDP. Consequently, public officers became cautious in granting interview hence, the study use the secondary data. The study made use of published journal articles, books, government information in gazette, newspapers and magazines, online information and other reliable sources.

\section{Conceptual Understanding of Insurgency/Terrorism}

The terrorist act is a function of aggression hence; the language of a terrorist is aggression. Aggression has no universal definition as it takes various forms and has a different meaning to different communities. Aggression emanates from disagreement within oneself while expressing dissatisfaction or aiming at fulfilling a task for a particular interest. It may be expressed by some parties or a group of individuals when a faction or a party wishes to lay claim to a proposed interest or where a party intends to have outright control or domination over others. These tendencies result in terrorist acts of different dimensions to bring others to submission. When feelings for aggression are fully established in individuals or groups, conflict erupts and the self-acclaimed powerful party begins to terrorize and create fear in the minds of the others including the ordinary people.

An online Cambridge Advanced Learner's Dictionary (2008) defines aggression as physical action or spoken behavior that involves the use of arms against or threatening someone or something. In a similar motive, the terrorists proclaim rights over others to enforce them to give up their rights for their interest just like the Boko Haram asked people of Nigeria to desist from investing resources and time on western education which encompasses the knowledge of scientific and technological knowhow based on reasoning and cognitive understanding via thinking and conscious mental application. It has to do with experimental and physical studies to justify empiricism. This may be fairly different form reading and learning. Its accomplishment may help learner to do better in the study of Arts subjects.

Merriam online Webster Dictionary also defines Aggression as a forceful procedural action intentionally meant to dominate or master especially when intended to dominate or master others. It expatiates further that the practice of making attacks or control; of the territorial integrity of one country especially by another and it is capable of initiating a war.

Insurgency is observed to be a full-scale premeditated aggression by any concerned group or individuals mostly non-state actor(s) in form of terroristic act, characterized by the intent to cause fear and precipitate violence acts to cause death as well as unimaginable inflictions against the opposing party mostly the constituted authority, the State, non-state actor or civilians to dominate or be in virtual control of affairs in dispute. In 2004, United Nations (UN) Security Council Resolution 1566 defined terroristic acts as

"criminal acts, including against civilians, committed with the intent to cause death or serious bodily injury, or taking of hostages, with the purpose to provoke a state of terror 
INTERNATIONAL JOURNAL OF ACADEMIC RESEARCH IN BUSINESS AND SOCIAL SCIENCES Vol. 10, No. 2, Feb, 2020, E-ISSN: 2222-6990 @ 2020 HRMARS

in the general public or in a group of persons or particular persons intimidate a population or compel a government or an international organization to do or to abstain from doing any act, which constitute offenses within the scope of and as defined in the international conventions and protocols relating to terrorism, are under no circumstances justifiable by considerations of a political, philosophical, ideological, racial, ethnic, religious or other similar nature, and calls upon all States to prevent such acts and, if not prevented, to ensure that such acts are punished by penalties consistent with their grave nature"

(UN 2004)

The Nigerian Law Commission defines terrorism in a broader scope as:

(a) A situation where the Leader/President or any person exercising the position of the Head of State, their successor, or the spouse of such person designated to uphold public functions or position is subject to death or bodily injury or deprived of liberty when they are being confronted with such act in their public capacity.

(b) Acts that specified to damage or destroy public utilities or property devoted to the public purpose. (c) Any act likely to subject or put human lives in the creation of public danger, in particular, the hijack of aircraft, subject the passengers to hostages as well as any form of violence inflicted on people under international protection or those who have diplomatic immunity.

(d) The production, supplying of arms, obtaining, or possessing explosive, ammunition, arms or harmful substances with an in intention to commit a terrorist act.

The conclusive clause in the adjunct section (c) above is partially outside the scope of this study as IDP does not enjoy diplomatic immunity because it has to do with internally displaced people, confined within the sovereign territory of their country; they are not refugees whose status enjoyed diplomatic immunity outside the border of their state. In an academic study, Tal and Yinon (2009) attribute terrorism to the fear-inducing violent acts by militaristic states as terrorism. In the characterization of aggression, the Bimodal Theory of Aggression according to Stanford, Houston, Mathias, Villemarette-Pittman, Helfritz, et al. (2003) found that aggression occurs in one of two forms namely "reactive" and "instrumental." The former occurs as a response to a situation perceived as a threat or provocation. Barratt (1991) posits that this form of reactive aggression is characterized by a reaction of panic or horror which causes inability to adapt behavioural sway. However, Meloy (2006) argues that a reactive form of aggression happens as a reaction for defensive motive that immediate and typically offensive in nature.

The second type of aggression means "instrumental" (also called tactical, premeditated, calculated, deliberate aggression) and attached with goal and objective, symbolized by non-emotional and autonomic arousal. The latter is more in line with militant and Boko Haram terrorist behavior as observed from their several inhumane attacks on the innocent citizens of Nigeria and that of the neighbouring countries.

\section{Pathological Perspective on Insurgent/Terrorist: A Theoretical Context}

It is found that those who carried out indiscriminate attacks on others are studied to be suffering from a particular psychological upset. Boko Haram insurgency activities are being carried out by 
different individuals who might lay claim to some pressing reasons to justify their actions. However, some theories show that the terroristic act emanated from a sort of abnormality and dysfunction in human behavioral standpoint. According to Silke (1998) personality, make-ups make terrorists psychologically different from non-terrorists. The conceptualization that was sourced from psychodynamic or contention posits that there are persons who have or lack personality traits that are more attractive with the feeling to involve in terrorist activities and perpetuate terroristic behaviour than those who are terror free minded (Ruby, 2002). The disorganized youthful life that promotes a poor sense of self and victimization towards any established authority is a defect model type of personality (Ruby, 2002). Kent and Nicholls (1977) observed that forcefully obeying authority results to a development or consequence of unconscious threat towards monitoring parents and is later planted in adult terrorist's rigid min-set while (Post, 84) shares the same type of terrorist unconscious hostility towards authority as an "anarchic ideologue" because of dysfunctional relationships with his parents especially the father. Alternatively, children that undergone stable upbringing with friendly parent relationship equally embarked on violent revenge in response to any mistake or intentional attack made against their parents are referred to as "nationalist secessionist". It is all in line with this conceptualization.

Strentz (1981) in Maile Jordan et al. explained that the "Leader" in terrorist group is the intellectual force or the "brains" of the terrorist operation who believed there should be logical change for the society as it is inadequate socially. The "Opportunist" is described as the "muscle" who is criminally minded with historical antisocial behaviour background. The last one is the "Idealist", young and willing to trust people and is expected to induce socio-political changes in the terrorist organization.

Based on developmental theory, LoCicero and Sinclair (2007) personality evolves by different factors such as environment, the parents as well as the peer of the terrorist influenced especially the group could shape the perception of the person with the group's ideology. However, in a dangerous environment, with violent attack, individual desire is more respected than group loyalty. The individual principle to resort to upholding the ideology to take arms in favour of the organization against the enemy.

In other words, proponents of these model placed priority to be or not to be a terrorist personological factors with no disagreement that contextual or structural variables may involve commission of such behaviour (Atran, 2003; Silke, 1998). In addition, there has not been general agreement or evidence for the need to incorporate multiple levels of analysis, ranging from individual, group, and societal levels and if incorporated it signified that terrorism is given psychological norm to terrorism with social political climate in their living environment according Crenshaw (1992, 2000).

\section{Internally Displaced People as Global Phenomenon}

The Internal Displace People (IDP) caused by the terroristic acts of aggression of some other people, natural disasters, and massive projects for development or otherwise has come to be identified and regarded as a phenomenon that needs special attention. It has to be technically addressed from all the circumstances that give rise to the problem while the effects that are directly related to it be tackled by humanitarian perspectives. Since it is understood that people flee for their lives in a 
situation where there are palpable signs of terroristic aggressive acts, the affected people certainly find it difficult to move with their properties. Therefore, the IDPs would unavoidably start a new life at a safe place. From this backdrop, the authority of the receiving state and the local administration are inevitably responsible to take up the primary responsibility of procuring the provision of the necessity of life such as shelter, food, clothing and social needs for the concerned members of IDP. The NGOs such as UNHCR are readily available and more prepared to provide the utmost necessary assistance for the IDP. The United Nations Organization agency in the name of the United Nations High Commission for Refugee UNHCR is a global agent charged with the responsibility of managing the IDP. It was established by the UN in 1950 following the industrial revolution in Europe and the aftermath of WWII to help those Europeans who have lost their houses to the war and have no place to stay and handling the refugees who have fled or lost their homes and sought protection in safe and peaceful places worldwide after. These situations gave rise to IDP establishment under UNHCR (UNHCR, 2001).

However, the main concern of this study is to look into the life and future ambition of the children among the IDPs in Nigeria even when studies have shown that IDP is a phenomenon and it happens worldwide. Cohen (2004) found that UNHCR's 54-year history of providing service to the refugees now confident to champion the service of protecting internally displaced persons. The author mentioned further that the emergency shelters' management and coordination and the IDP camps will be the responsibility of UNHCR. The current estimate of IDP by conflict, violence, and disaster worldwide is 31.1 million as of 2016 , the figure is equivalent to a person per every second is forced to flee (IDMC, 2017). The graph below shows that 78,000 persons were forced to flee in Nigeria as due to disaster and 501,000 people owning to conflict. In total, Nigeria accounts for 579,000 IDPs. China, Philippine, India, Indonesia, and the USA and Japan have experienced a high turnout in IDP from the disaster while Africa and a part of Asia have a higher percentage of Conflict IDP. The Arab Republic of Syria, Iraq, Afghanistan, the Democratic Republic of Congo, and Nigeria are responsible for higher number of disaster IDP as of 2016.

In Table 1: below, the study features only the group of nations reported to have accounted for over 500,000 IDP either as a result of disaster or conflict. Many other nations are known to have experienced a form of disaster or conflict such as Ethiopia and South Sudan in Africa but with low estimated IDP. Any nation with a figure of IDP less than half of a million (0.5million) is not featured to be briefed. For the benefit of receiving humanitarian support, integration and human rights status, the Guiding Principles are being adopted. 
INTERNATIONAL JOURNAL OF ACADEMIC RESEARCH IN BUSINESS AND SOCIAL SCIENCES Vol. 10, No. 2, Feb, 2020, E-ISSN: 2222-6990 @ 2020 HRMARS

\section{Table 1: The Internal Displace People (IDP) by Country}

\begin{tabular}{|l|l|l|}
\hline Countries & Disaster & Conflict \\
\hline China & $7,434,000$ & -- \\
\hline Philippine & $5,930,000$ & - \\
\hline India & $2,400,000$ & - \\
\hline Indonesia & $1,246,000$ & - \\
\hline Cuba & $1,079,000$ & - \\
\hline Japan & 864,000 & - \\
\hline Bangladesh & 614,000 & - \\
\hline Myanmar & 509,000 & - \\
\hline Democratic rep. of Congo & -- & - \\
\hline Syria & -- & 922,000 \\
\hline Afghanistan & -- & 824,000 \\
\hline Iraq & -- & 653,000 \\
\hline Nigeria & 510,000 & 659,000 \\
\hline
\end{tabular}

Excerpt from IDMC GRID, (2017) Global Report on Internally Displaced People (IDP) by Conflict and Disaster, Norwegian Refugee Council. Retrieved from http://www.internal displacement.org/globalreport/grid2017/

In Africa, Angola is the first country in the world to incorporate the Guiding Principles into domestic legislation, with the Norms for the Resettlement of displaced populations. The countries like Uganda, Georgia, Burundi and Columbia, expressly referenced the Guiding Principles in their different country's laws and policies (Background Paper, 2006).

In the case of Nigeria, the internal displacement policy is just being given attention to the develop a draft, addressing all its probable causes, including conflict, natural disaster, and development projects (Oduwole and Fadeyi, 2013).

According to the Table 2 below, there are countries with a higher number of victims of conflict and violence IDP; those shown in the table are well above 500, 000 as of 2016, as extracted from the IDMC, published data. The state of Columbia has the highest number of IDPs because of its rebellious group known as the Revolutionary Armed Forces of Colombia, (FARC) which had killed about 260,000 people and millions displaced in the 52-year conflict (BBC, 2016 October 6). The second highest IDP on the table 2 is the State of Syria with above 6 million IDPs emanated from the war between the rebellious groups, the Islamic terrorists and the government troops since 2013 while the least IDPs are in Myanmar during the ethnic conflicts between the state and the ethnic Rohingya Muslims which was referred to as "ethnic cleansing" by the Donald Trump's administration in the United States of America while the least IDP figure was in Azerbaijan as a result of territorial conflict with Armenia in western Azerbaijan (iDCM 2014 March 26). 
INTERNATIONAL JOURNAL OF ACADEMIC RESEARCH IN BUSINESS AND SOCIAL SCIENCES Vol. 10, No. 2, Feb, 2020, E-ISSN: 2222-6990 @ 2020 HRMARS

Table 2: Showing the Nations with High-level IDP above 500, 000 victims from Conflict and Violence in 2016

\begin{tabular}{lc}
\hline Countries & IDP above $\mathbf{5 0 0 , 0 0 0}$ \\
\hline Columbia & $7,246,000$ \\
Syria & $6,326,000$ \\
Sudan & $3,300,000$ \\
Iraq & $3,035,000$ \\
Democratic Republic of Congo (DRC) & $2,230,000$ \\
Yemen & $1,974,000$ \\
Nigeria & $1,955,000$ \\
South Sudan & $1,854,000$ \\
Ukraine & $1,653,000$ \\
Afghanistan & $1,553,000$ \\
Turkey & $1,108,000$ \\
Somalia & $1,107,000$ \\
India & 796,000 \\
Myanmar & 644,000 \\
Azerbaijan & 582,000 \\
\hline
\end{tabular}

Excerpt from iDMC Internally Displaced people by Conflict and Violence as of 2016

Figure 2: Showing the Nations with High-level IDP above 500, 000 victims in 2016 Number of IDP (in millions)

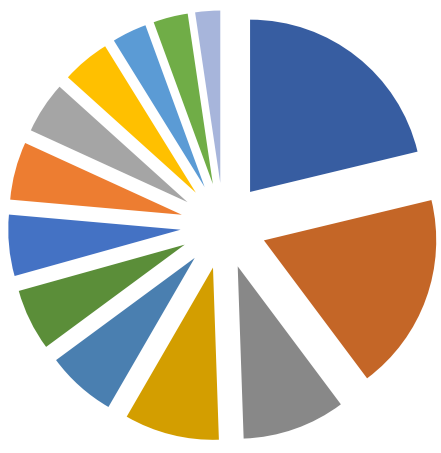

Columbia
Syria
Sudan
Iraq
DRC
Yemen
Nigeria

The pie chart expresses the size of refuge in IDP of each country stated in Table: 2 above

The United Nations Convention on the Rights of the Child (CRC or UNCRC) is a treaty on human rights which is related to the civil, political, economic, social, health and cultural rights of children (UNICEF, 1990). Article 1 of the Convention defines a 'child' 'child' as a person below the age of 18 unless the laws of a particular country set the legal age for adulthood younger. The Committee and the monitoring body for the Convention thereafter encouraged States to review the age of majority if it is set below 18 and to increase the level of protection for all children under 18 (UNICEF, 1990). This is a direct indication that whatever the condition of children involved in IDP, their rights should be 
INTERNATIONAL JOURNAL OF ACADEMIC RESEARCH IN BUSINESS AND SOCIAL SCIENCES

Vol. 10, No. 2, Feb, 2020, E-ISSN: 2222-6990 @ 2020 HRMARS

respected and protected. It means, there would be special arrangements for their course not only to survive the negative outcomes of the unfortunate situation of displacement they suddenly found themselves but they must also be rightly guided to fulfill their ambition in life possibly, through education and vocational training.

\section{The Child Rights and the Legal Framework}

By the end of 2016, conflict and violence had forced 40.3 million people in the world to seek abode in in IDP. Surprisingly, over half of a decade since 2000, the number has increased to a double size. Before 2016, various disasters had rendered many victims displaced. The UNICEF's Article 4 (Protection of Rights): Children 's right and protection are priorities to uphold by governments with all available measures and fulfilment. All countries that ratified the Convention are mandated make review of their children's related laws. The Convention embraces the need to review health, social, legal and education systems among others. It includes the fact that government should help family so that children achieve potentials in a conducive environment even if it requires changing or creating a set of new laws. (UNICEF, 2005). The General Assembly World Summit Outcome in the summary of the rights changing of the child, Article 141 "expresses surprises at the huge number of kids caught in the act of armed conflict, including domestic violence, exploitation, trafficking sexual abuse. The Summit outcome gives backing to cooperation policies that empowers national strength to up-turn the life of those children by provision of assistance and rehabilitation that can facilitate integration in the society.

In situations of displacement, stray children have no access to education. Hence, the United Nations Guiding Principles on Internal Displacement (1998), 29 in principle 23 appeals to government to give free and compulsory education to the children that are internally displaced children in their individual cultural identity, language and religion with special attention to focus on girls' participation.

\section{The African Union Convention for the Protection and Assistance of Internally Displaced Persons in Africa (Kampala Convention)}

The Federal Republic of Nigeria founded an organization named The National Emergency Management Agency of Nigeria, (NEMA) established via Act 12 as amended by Act 50 of 1999, to manage disasters in Nigeria (NEMA Official website). Its areas of expertise include training, search, and rescue of victims. Finance and administration of the games involved and provision of relief and rehabilitation are parts of its major tasks. The main collaborators with NEMA on its tasks include the Federal Road Safety Commission, Federal Fire Service, Nigeria Security \& Civil Defense, and the Nigeria Red Cross. One of the key tasks of the NEMA according to (Act 1999: 1a) is the formulation of policy on all activities relating to disaster management in Nigeria and the coordination plans and programs for an efficient and effective response to disasters at the national level. In the Part II section $f \& k$, of the Law of Federation, the Acts empowers the Agency to coordinate and facilitate the provision of necessary resources for search and rescue and other types of disaster curtailment activities in response to distress call while subsection (k) allows the agency to liaise with State Emergency Management Committees established under section 8 of this Act to assess and monitor, where necessary, the distribution of relief materials to victims of disaster. From these backdrops, the 
INTERNATIONAL JOURNAL OF ACADEMIC RESEARCH IN BUSINESS AND SOCIAL SCIENCES Vol. 10, No. 2, Feb, 2020, E-ISSN: 2222-6990 @ 2020 HRMARS

Federal Government of Nigeria has adequately decentralized authority for NEMA to facilitate efficient emergency management in any eventuality of disaster for the IDP.

\section{Challenges Faced by the Internal Displaced People (IDP}

However, the study found the following issues in the condition and welfare of the IDP in Nigeria. After the Boko Haram Islamist militants have militarized the North East of Nigeria and unleashed the acts of terror on the people across the cities and villages, many people who escaped death were displaced including the children, the children of dead and wounded victims. They were made to settle down in various camps across the nearby states and local government areas in the northern parts of Nigeria. In an interview conducted by a media organization in one of the IDP camps in Abuja to one member of the IDPs, he lamented that:

Health parastatals are concerned about the outbreak of meningitis; they don't know that if one of the IDPs gets infected, because of the congestion here in the camp, the whole community and by extension, Abuja is threatened. Hospitals suddenly withdrew subsidy used to treat IDPs, they have refused to comply with the documented directive from the Federal Government to treat IDP in government hospitals. Next to that, we have a lot of students, and some structures have been put in place for the children to learn but no materials, no teachers

(The Authority, 2017 April 18).

In an assessment of the population of those in the Abuja IDP Camp of 2, 538 persons, 713 are youth, $70 \%$ of the IDPs are female out of which 520 of them are women with children. In further interaction, the interviewee pointed out regrettably that:

"It is so sad that the government has ignored us, the last donation from the government to the IDPs were packs of Mosquito coil, that was in September 2016, before then was in 2014, when they brought 20 bags of rice, all labeled with (GEJ) The acronym for Mr. Goodluck Ebele Jonathan, the immediate former President of Nigeria's portrait and that was political"

(The Authority, 2017 April 18).

It was found that an elderly woman among the IDPs with knowledge of the orthodox method of delivering babies had delivered over 100 babies for the expectant mothers through the traditional methods without the involvement or participation of any hospital medical attendants (The Authority, 2017). Out of 20 states of Northern Nigeria, the IDP camps have been established across 13 states with a total of 2 million Internally Displaced People. Borno state shared a total of 1, 434, 149) while the federal capital territory, Abuja shared the least totaling (13, 181 IDPs) See iDMC (2013-2017).

According to Voice of American (VOA) reports, the Nigerian enemy is not only the insurgency of Boko Haram but the most dangerous enemy that hampered the army effort is corruption. Nigeria's Vice president mentioned that $\$ 15$ billion was spent lavishly on shoddy arms procurement deals alone. Transparency International (TI) found that Nigerian military officers, politicians and other elites have corruptly diverted funds that was meant to fight terror. The report mentioned that a part of the fund 
was paid to unauthorized workers not found on pay-roll record, via kickbacks or for contracts inflated contracts that benefit only politically connected contractors (VOA, 2017). The Premium Times (2016) reports that sixteen soldiers and four officers of the Army Division 7, Nigerian Army in Maiduguri, Borno State were to be tried by a setup a court-martial for committed crime of sales of arms to the civilians as well as abuse of human rights during the ongoing war against Boko Haram in northeast Nigeria.

Figure 1: below shows the health condition of children in the Durumi and Bama IDP camps in Borno State. The appearance of the children had revealed the extent of malnutrition and lack of care that clearly shown on the children. The figures indicate that the children were not well fed possibly due to inadequate food supply and they did not have access to medical attention. The Nigerian president Muhammad Buhari was unhappy and called for immediate meeting with the stakeholders when photographs and news of the death of children in IDP released by the by Doctors Without Borders (MSF) showing malnourished persons in the camps (Nigerian Eye, 2016) the picture went viral as a result of lack of food supplies. It has been shown in the literature that food items are being hijacked in the camp and its direct result is clearly shown on the children. Subjecting the children to serious malnutrition has health consequences that may leave with the children for a long time in their lifetime. The clothes found on the children are very dirty and extremely unhealthy for human needs.

\section{Figure 1: Image of some of the children in the IDP camps in Nigeria}

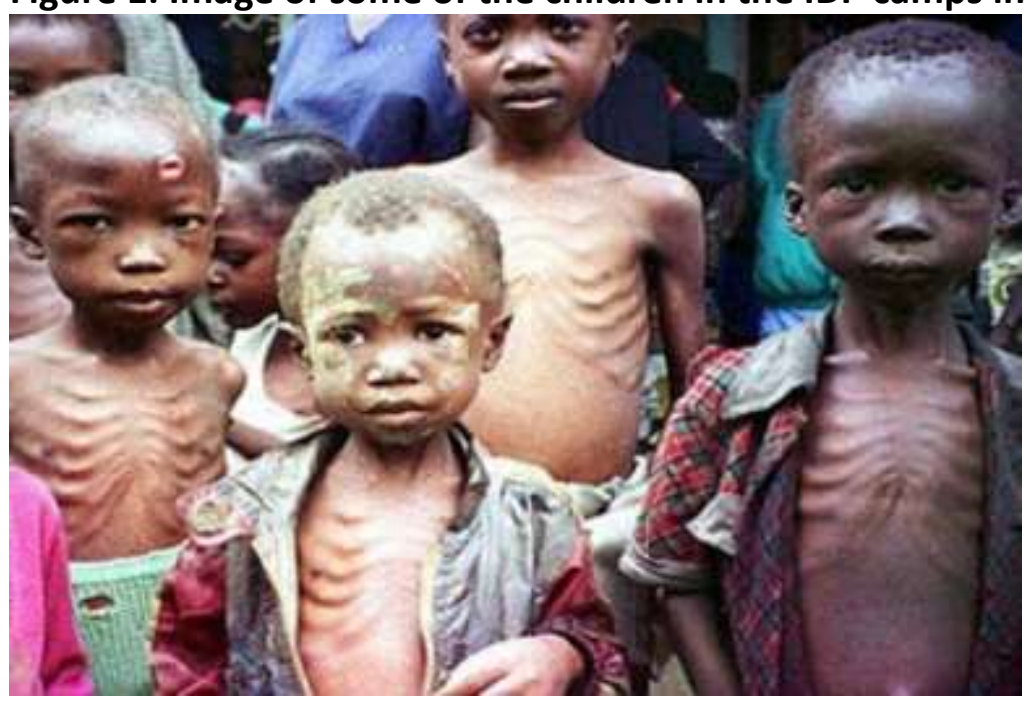

Princewill Ejikeme's Blog (November 5, 2016)

Severe Acute Malnutrition Ravaging IDP's Camp in Nigeria. Retrieve on 3 March, 2018 from https://pejikeme.wordpress.com/2016/11/05/severe-acute-malnutrition-ravaging-idps-camp-innigeria/ 
INTERNATIONAL JOURNAL OF ACADEMIC RESEARCH IN BUSINESS AND SOCIAL SCIENCES Vol. 10, No. 2, Feb, 2020, E-ISSN: 2222-6990 @ 2020 HRMARS

\section{Figure 2: Evidence of Malnutrition militating against the Children in IDP}

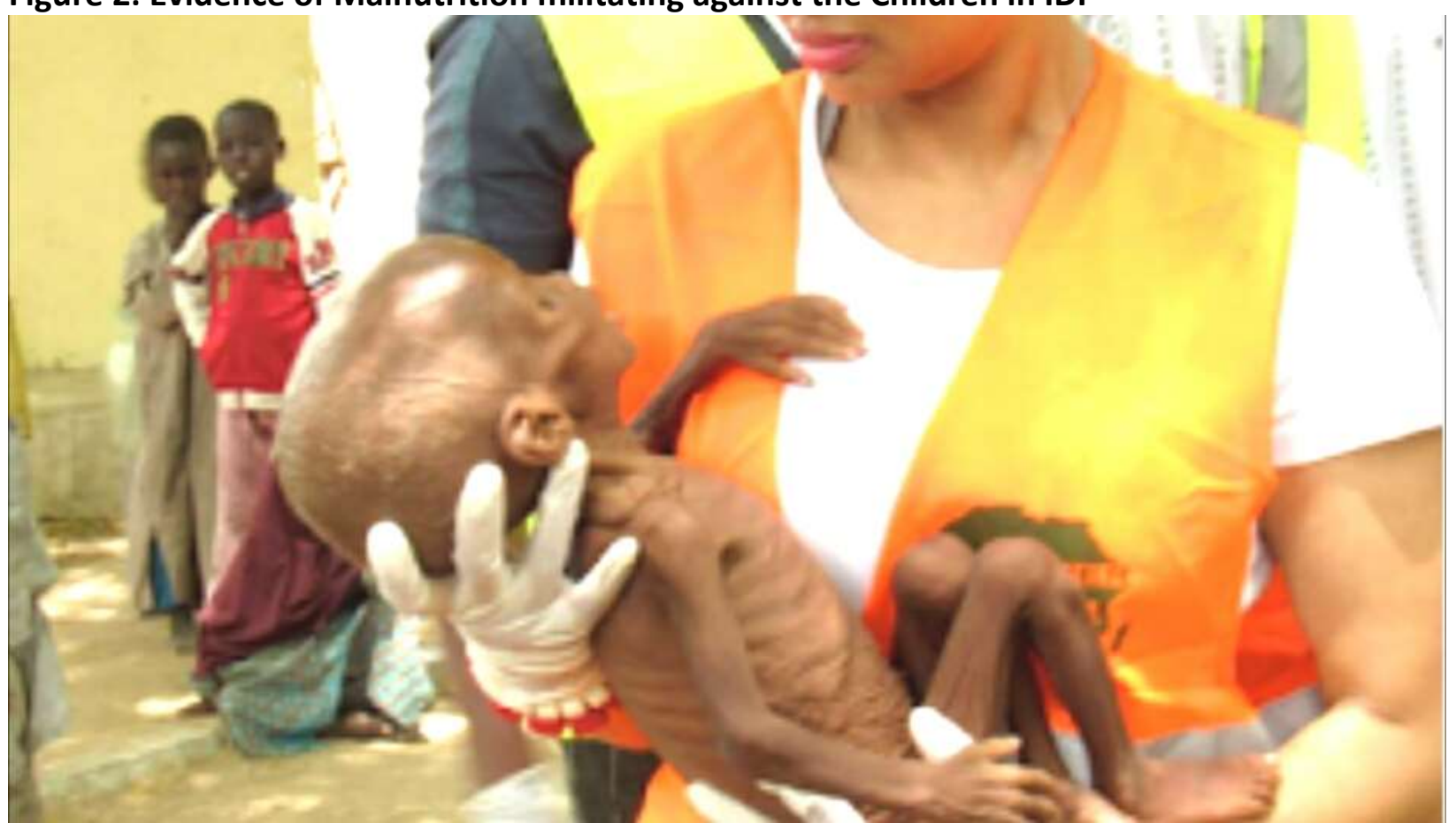

Nigerian Eye, (2016). Retrieved on march 52018 from http://www.nigerianeye.com/2016/06/panicgrips-officials-as-buhari-seeks.html

Chika Jones in Naij.com online news (2017) observed that the lack of proper and adequate food in IDP's camp is a problem although the state governments, National Emergency Management Agency (NEMA) and State Emergency Management Agency (SEMA) are in charge of the camps. The report reveals that donations from philanthropists like Dangote (The richest man in Africa) and other politicians are mismanaged while food meant for the IDP camps diverted. He found that people charged with the responsibility of distribution of food and other material were accused of corrupt behavior while caught offering the free food for sale at higher prices hence aggravating children' malnutrition and suffering for all.

On 17 January 2017, a fighter jet of the Nigerian Air Force while targeting to wipe out a Boko Haram insurgents' hideout, accidentally hit an Internally Displaced Persons' (IDPs) camp at Rann, Borno State with bomb, killing 52 workers, civilians and over 200 others were injured as reported by (Vanguard, 2017). The camp that was hit with bomb was originally set up in March 2016 to host 43,000 internally displaced people in north-east Nigeria (UNHCR, 2017). The military high command had taken responsibility and apologized. Many eventually suffered great losses such as family members, while fathers, mothers, sons, and daughters could not be verified if they are dead or still alive elsewhere. The report mentioned that IDP of over 1.7 million as well as humanitarian agencies, are still under threat and safety challenges as government security forces and Boko Haram engaged attacks against each other. 
Taking good care of children in any location they found themselves is more beneficial to any nation because a group of healthy educated and brilliantly knowledgeable children would build the future for the furtherance of the sustainable social, economic and the entire societal development.

Education is the key factor to compensate the orphans, children in particular that had experienced trauma from the loss of either parents and guardians or friends and relatives. The report gathers revealed that many of the teaching supplies to train the children as well as the food items are treated with corrupt attitude. Those children that the effect of insurgency forced to terminate schooling faced continual defects in their education in the camp (Jones, 2016). Osayimwen (2017) reiterates that a non-governmental organization school built at the IDP camp to rescue the youth in education was locked for lacked in May 3rd, 2017 for lack of funding hence; a few teachers remained behind to provide teaching services.

According to Osayinwen (2017), a young teacher underlines in Durumi camp and laments the neglects toward provision of necessary facilities for education of children in the camp. However, the teacher provides children with some refreshments to gain their attention in class. Despite the admirable efforts of the remaining teachers, the study points out that to achieve a sustainable education for all those vulnerable youth is not feasible soon because of the impediments while no education is found in other camps and this may complicate the children's future.

\section{International Humanitarian Agency Assessment}

According to McCarthy AnneMarie contribution to IDPs situation in the Daily Trust (2016) in summary, reiterates that:

Those who feel the brunt of migration as they are ripped from their communities, removed from school and often end up orphaned or abandoned are the children. In addition, only 60\% of schools are opened for operation while 30\% of IDP, mostly girls as young as 6 years are abused sexually while education of 19,000 is terminated 600 teachers were murdered. About 1200 schools suffered destruction or were damaged because they served as temporary housing facility for the IDP. Since 2013,600,000 children have no access to education.

A series of attacks on the UN refugee management convoy and their officer's workers are exposed to frequent disruptions in the distribution of essential items to the IDP in various camps continue to make work slowdown and cumbersome. Some of the people attacked were wounded. The security situation in and around the northeastern Nigeria is a serious concern. The safer way to have access to the refugees in their camp to provide them with interventions is the major concern of the NGOs as UN refuge officer stated. While lamenting on the difficulties confronting the workers, she express satisfaction in the effort of 'Plan International' as one of the NGOs accessed the refugee camps, in Nigeria, Niger and Cameroon, the destinations of thousands of fled displaced people of Northeast of Nigeria. Attacks on Humanitarian Workers as they struggle to make life better for the people, they continue to put their lives at risk within conflict-affected countries. In the last 10 years, over 1,000 of humanitarian workers have lost their lives across the globe over (McCarthy AnneMarie, 2016 August 11). 
INTERNATIONAL JOURNAL OF ACADEMIC RESEARCH IN BUSINESS AND SOCIAL SCIENCES

Vol. 10, No. 2, Feb, 2020, E-ISSN: 2222-6990 @ 2020 HRMARS

The statistical figure in Table 3: below is based on an assessment conducted from November to December 2015 by the International Organization for Migration's (IOM) Displacement Tracking Matrix (DTM) team in 207 Local Government Areas (LGA) covering 13 States of Northern Nigeria: Abuja (13,481 IDPs); Adamawa (136,010); Bauchi (70,078); Benue (85,393); Borno (1,434,149); Gombe (25,332); Kaduna (36,976); Kano (9,331); Nasarawa (37,553); Plateau (77,317); Taraba (50,227); Yobe (131,203); and Zamfara $(44,929)$ (IOM/NEMA).

Table 3: 207 Local Government Areas (LGA) covering 13 States of Northern Nigeria

\begin{tabular}{l|c|}
\hline State & No. of IDP in Each State \\
\hline Borno & $1,434,149$ \\
Adamawa & 136,010 \\
Yobe & 131,203 \\
Benue & 55,393 \\
Plateau & 77,317 \\
Bauch & 70,078 \\
Taraba & 50,227 \\
Zamfara & 44,929 \\
Nasarawa & 37,553 \\
Kaduna & 36,976 \\
Gombe & 25,332 \\
Abuja & 13,481 \\
Kano & 9,331 \\
\hline Source: iDMC, (2016). Nigeria IDP Figures Analysis Retrieved from http://www.interna \\
\multicolumn{1}{c}{ displacement.org/sub-saharan-africa/nigeria/figures-analysis }
\end{tabular}

In Table 3; which shows the distribution of the IDP population in each camp in the Northern part of Nigeria, the higher number of displaced people is found in Borno state. One of the reasons for this fact is that Borno is big and closed to the location that housed the Boko Haram terrorist group and Maiduguri is the capital of Borno. There is enough space where a temporary place can be cleared and prepared to build a camp for a larger number of IDPs. The camp housed almost seven times of the population that Yobe and Adamawa states take individually. Kano has the least IDP in the north even though it has a very large space. However, it is the highly populated state in the Northern part of the country. The terroristic acts of the Boko Haram have displaced many civilians across the neighboring states and beyond in Nigeria and this has economic and social impacts on the people's lives. The report indicates that these IDP figures are preliminary estimates that are subject to review in the context of the finalization of IDMC's 2016 yearly report on internal displacement, to be published in May 2016.

Below are the highlights of the IDP updates particularly the children in the following excerpt: In a report released by the UNICEF and partners Response in (2017) the estimates of a total of 1.69 million are in IDP Adamawa, Borno and Yobe, of which 85 per cent are in Borno alone in Northeast Nigeria. 
INTERNATIONAL JOURNAL OF ACADEMIC RESEARCH IN BUSINESS AND SOCIAL SCIENCES Vol. 10, No. 2, Feb, 2020, E-ISSN: 2222-6990 @ 2020 HRMARS

- A total of 57,467 children under 5 suffering from severe acute malnutrition were admitted into treatment, including 3,297 reached during the reporting period.

- A total of 62,279 children received psychosocial support through Child friendly spaces and child clubs, including 14,920 during the reporting period.

- So far in 2017, 425,021 children accessed safe learning through temporary facilities and schools, of which 3,307 were reached during the second half of June

(UNISEF \& Partners, 16-30 June 2017)

\section{Review for Research Gap}

In a pathetic report released by the Nigerian Human Rights Watch (HRW) (2016 July), it was revealed that some officials of the government and that of other authorities in Nigeria were accused to have raped and sexually exploited women and girls who were displaced following Boko Haram violent attacks. It mentioned weakness on the part of the authorities to provide adequate protection or sanction the abusers, reported to include camp leaders, vigilante groups, policemen, and soldiers and that the displaced people have no access to basic rights and services. In late July, 2016, the Human Rights Watch reported to have documented sexual abuse, including rape and exploitation, of 43 women and girls living in seven (IDP) camps such as Abadam, Bama, Baga, Damasak, Dikwa, Gamboru Ngala, Gwoza, Kukawa, and Walassa, displaced from several touwns and villages in Maiduguri, the Borno State capital after spending months in military screening camps.

Olusegun and Ogunfolu, (2019) published an article titled Protecting Internally Displaced Children in Armed Conflicts: Nigeria in Focus reiterate that little attention has been given to the legal protection of the children who have been internally displaced in Nigeria. They were subjected various forms of abuse which could affect their development and wellbeing. Thus, the article seeks to discuss and analyzes the international protection policy of internally displaced children, both in human rights and humanitarian laws, in addition to their legal protection in Nigeria and recommends solutions to the challenge of internally displaced children in Nigeria.

The Universal Declaration of Human Rights (UDHR) in 1948 by the United Nations after the Second World War11 was meant to ensure world peace and avoid a repetition of the horrors meted out to minority groups and prisoners of war during WWII. The declaration recognized the inherent dignity, equal and inalienable rights of all members of the human family (UNICEF, 2007). These include men, women and children. As stated by UNICEF (2007), children 's rights are human rights for children and people under the age of 18 years. This is vital for protecting the best interests of a child. The Child 's Rights Act, 2003 provides that the best interests of a child should be central in all considerations. A child shall be given such protection and care as it is necessary for its wellbeing, retaining the right to survival and development and to a name and registration at birth (UNICE, 2007) 
Itumo and Nwefuru (2016) published an article entitled Insurgents: Implications for Socio-Economic and Political Development. The research found that the IDPs in the north east suffer challenges of starvation, accommodation, unemployment, school dropouts, sexual harassment, child labour, early marriage, poor health and sanitation, with implications of standard of living and development of Nigeria. The study did not focus on the condition of the children but mentioned starvation at the IDPs. Human Right Watch (2014) reports that in 2013 alone, 300, 000 people fled Borno, Adamawa and Yobe, out of which seventy percent of them are said to be women and children.

Another study by Tari, Kibikiwa and Umar (2016) titled: The effects of Boko Haram insurgency on food security status of some selected local government areas in Adamawa State, Nigeria reveals that food security in Adamawa State is no longer guaranteed because of the displacement of the farmers from their usual livelihood (mainly agricultural activities). The study established that malnutrition especially among the displaced children in the study is on the high level. Based on the findings of the study, there is need for government and Non-Governmental organisations (NGOs) to help to address malnutrition and other related issues among children, especially those under five years. The author suggested that -Special agricultural programs and policies should be initiated in order to resuscitate agricultural potentials of the attacked zone.

\section{Research Gap}

Most of the reviewed studies on the insurgency limited their findings on the activities of the Boko Haram and the different effects. The effects range from violent attacks on innocent people, government institutions, violation of war ethics, displacement of war victims, food shortages, assaults committed against the vulnerable segment of the society such as the women, the aged, children and the disabled persons, manslaughter, murder, arson to kidnapping and many other reported war crimes. However, the difference in those studies to the research under context is that some of them mentioned the children as vulnerable who could not withstand the tense situation of war and the devastations reported as the aftermath of terrorist activities. None of them focus the study on the fate of the children and the need to rescue them in their required educational/vocational knowledge to ensure they achieve their ambition via their inbuilt talents. The children were truly becoming element of abuse in the hands of some criminally-minded individuals who infringed on the rights of the children and women by abusing their position of power not to mention of the Boko Haram terrorists' group inhumane activities and the effects. However, the previous studies for instance, HRW series of reports addressed abuse of the refuges by the members of the vigilante, some government officials as well as local camp workers but fail to address and implement pragmatic, long term sustainable solution to the education and future of the children to attain future ambition.

\section{Findings and Analysis}

The upsurge of the Boko Haram group members has its link to many factors. For instance, unemployment is as high as over 12.1\% of Nigerians in Q1 2016 (not including an additional 19.1\% underemployment) which is higher than the global average of the workforce. Apart from the fact that idle hands are accessible instruments of Devils, some financially-imbalanced individuals would be ready to provide any service demanded of them in exchange for financial inducement to care for them and their family. This may have supported the high number of recruits found in the Insurgent 
groups in the Niger Delta region in the south and the Boko Haram in the north. The failure of the government to procure adequate and up-to-date arms and ammunition for the army to confront the insurgent groups and to prevent the escalation of criminalities proved the victorious engagement of the insurgents against the national army for a while. Insurgent groups were not decisively confronted until the group successfully embarked on a kidnapping spree. They attacked schools and residents and villages.

They kidnapped the school children, they treated girls among them with abuse, put them in forced marriages and the males for recruitment as child soldiers, undercovers and casual helpers. Later, over 276 Chibok secondary school girls were successfully abducted by the Boko Haram terrorist group on the 14 April 2014 (Maiangwa and Amoo, 2015). Inadequate provision of weaponry to confront insurgencies was linked to the lack of government's will especially during the regime of President Goodluck Jonathan (2010-2015). This unwillingness was identified when investigation unfolded that the fund set aside for the purchasing of weapons for the Nigerian Army was reported to have been corruptly distributed among the members of the PDP ruling party to engender people's support at the poll in the subsequent 2015 General Elections.

However, the well trained but unequipped army was massacred by the unprofessional terrorist members of Boko Haram. Corruption in the public sector played a significant role in the causes of loss of members of the Nigerian army and innocent citizens of Nigeria into the hands of Boko Haram insurgents which invariably accounts for an increase of helpless and defenceless IDP. This directly implies waste and embezzlement of public funds equal to US\$15 billion. The lack of political will on the part of the government inhibits the provision of adequate security for the people and ammunition for the army to fight the Boko Haram groups and other insurgents.

The outcome equally accounts for the government's inability to provide adequate security capable of protecting the IDP camps across the nation. This failure conceived the lack of provision of adequate and up-to-date educational facilities to train the children for a better future and protect the life of the children in most of the IDP camps. The ministry of education did not see anything good in building sustainable temporary schools for the IDP students or deploying enough teachers that could deliver in the camps. Lack of proper monitoring of Philanthropists' humanitarian gifts opened avenues to corrupt IDP guides to treat themselves to the resources meant for the poor IDPs and the provision for their children the orphans among them with contempt. In fact, it is understood that the government leadership is confronted with a series of insurgencies from the North-East, the SouthEast and the South-South regions and its troops could not subside the effect to the minimal level.

However, efficient controlling mechanisms through monitoring, reporting and immediate resultoriented prosecution and confiscation of properties of perpetrators and that of the saboteurs of government policies by the EFCC and other relevant agencies may have served as effective deterrent to save a lot of funds drained by the enemies of national progress. The incessant delay of prosecution, conclusion and conviction of most of the high profile corruption cases in courts, coupled with the insincerity of the judiciary in discharging duties timely and transparently motivate the Nigerian politicians and public officers to see corruption related crimes as most lucrative business in the Nigerian public sector. 
A senior advocate of Nigeria, a member of the Bar and Human rights lawyer revealed during an interview with the media that "senior lawyers know all corrupt judges and court officials" and that "the information is freely circulated among lawyers" (The Nigeria Lawyers, 2017 October 6). This revelation from an insider in the Nigerian Judiciary should have been taken with seriousness and be investigated by the government's security operatives as an opportunity to clean and make the judiciary a corruption-free arm of Nigerian government. This is possible by adopting a mass retrenchment of judges found wanting on the account of compromising judicial profession. This development led to some sudden scrutiny embarked upon by the security that led to the removal and subsequent retirement of the Chief Judge of the Federation and some judges caught in the acts of sabotaging the rules, order and code of judicial conducts in the Nigeria Judicial System. However, many of the Nigerian corrupt judges managed to escape the drag-net but it is advisable the clampdown exercise remains a continuous exercise with sincerity of purpose if Nigeria should be a crimefree and corruption-free society.

Along this finding, the government should be held accountable for the multiplicity of cases of corruption and other types of crime perpetrated against Nigerians and their socio-economic status. However, in return, the effects of the dysfunctional system of governance fall on the poor, helpless and voiceless members of the public. As the public funds allocated for the security of the lives and properties instead of being appropriated for peoples' social needs and nation-building ended up in private pockets of corrupt public officers and the politicians. What punitive measure has the government taken against the individuals indicted and prosecuted over the unlawful embezzlement of $\$ 2$ billion earmarked to procure arms and ammunition to fight insurgency? How much or what percentage of the amount has been refunded by the individual culprits? What preventive measure has government put in place besides the anticorruption institution whose leadership remained unconfirmed by the Legislative arm of the government? There are reports that in the Nigeria judiciary, there still exist some unpatriotic judges operating in the shadows.

Nigeria is having one of the highest figures in percentage of unemployment of the youth in the world today (15-24years at $21.5 \%$ in Q1 2016, it was estimated at 56.1\% using the old methodology) up from 19.0\% in Q4 2015 and 17.8\% in Q3 2015) (National Bureau of Statistics, 2016). However, the IDP camps are ironically suffering from inadequate staff that can cope with the needs of children and civilians therein. What made the government's agents or the organizations in charge of IDP fail to recommend to the government the need for more relevant staff while many Nigerians are unemployed? Most of the people sheltered in the IDP are poverty-stricken; therefore, prolonged inadequate feeding for them and their children made life worse as malnutrition gives rise to other life-threatening diseases for the children as seen in the figure .

The news of corruption and act of sabotaging the effort of the military were a strong motivation for the Boko Haram which indirectly made the Islamic group victorious in their barbaric acts of killing the civilian through the suicide bombing strategy as well as displacing millions of underprivileged children during violent attacks in the absence of security operatives. The study calls for timely response to 
INTERNATIONAL JOURNAL OF ACADEMIC RESEARCH IN BUSINESS AND SOCIAL SCIENCES

Vol. 10, No. 2, Feb, 2020, E-ISSN: 2222-6990 @ 2020 HRMARS

rescue the children to have a better future in life as they are the next in generation to engage in nation building.

\section{The Way Forward}

The Nigerian government through its policymakers and disaster management agencies such as NEMA should work tirelessly with the office of the UN Secretary-General to design strategic solutions against the terroristic attacks of the Islamist in Nigeria. The Nigeria National Emergency Management Agency and other humanitarian agencies such as; the groups in the forefront of the awareness creation on security consciousness include Youths Against Disasters (YADI), Executive Volunteer Group (EVG), Emergency Youth Vanguards (EYV), Journalists Against Disasters (JAD) among others should form formidable block to reduce the catastrophic state of the children and the elderly. The outcome of the UN World Summit in UN Doc A/60/L.1 paragraph 81 strongly condemns terrorism in all its forms and manifestation. Paragraph 118 of the aforementioned Summit call upon all States concerned to take concrete measures to ensure accountability and compliance by those responsible for grave abuses against children. The UN also reaffirms its commitment to ensuring that children in armed conflicts receive timely and effective humanitarian assistance, including education, for their rehabilitation and reintegration into society.

The presence of IDP and other forced migrants, if controlled with adoption of European Union framework on IDP can also result in new opportunities and benefits to the economy at local and national levels. This is based on effective engagement of refugees' human capital, by providing training to acquire skill for the labor to be able to provide enough and standardized goods and services. It proves to be steps to incorporate the skillful and physical ability of the refugees to drive economic growth and improve their self-independence. Their feelings of being economically viable to sustain themselves and contribute to public goods would thereby motivate, excite and strengthen the quality of refugees' mental and physical state of being. The useful engagements under state's recognition and acknowledgement of their contribution would significantly reduce the effects of the tremour and psychological imbalance they had experienced during terrorists' attacks on their lives. They would be pragmatic in devising better means of protection of lives and property in the future and that measure also serve as benefit for the host countries as health related issues and the cost of providing care would definitely reduce.

The Federal Ministry of Education and other stakeholders should embark on a policy of establishing schools for the IDP and more teachers must be deployed to the IDP camps to build a good future for these children. That development will provide adequate knowledge to the children therein and its long-time effect would be the basis for sustainable development for the nation. Proper feeding and adequate provision of health facilities for the IDP and the children, in particular, are of immense importance as a way to save the youth for future development. It is a duty as a matter of importance for the local and international agencies to establish a specialist hospital equipped with a sophisticated Pediatric section for the infants and newly born children.

As life goes on in the IDP where many families resided, provision for obstetrics and gynecology in a well-established health center is required in every IDP camp with adequate and well trained medical 
staff that could provide adequate health care for the women and the vulnerable members of the IDP community. Long term planning is required for the life of the children as the government may arrange vocational training for the children by signing an agreement with many professional trainees in scientific and technological know-how organizations such as electrical and automobile mechanical works. Others are Information technology industries and Smartphone technician work or food processing organizations to train the children while they continue receiving education.

Transport and other necessary logistics should be made available to ease movement at a very cheap cost since most of the IDP has no opportunity to conduct elaborate businesses in such unsafe places like the unfortified camp's structures which are meant to be temporary residents for the IDPs. Microcredit facilities may need to be granted to most of the women in the IDP to enable them start private businesses while the government makes proper use of civil servants and professionals among them in what they know best to create jobs and training for others. All the resources donated by the philanthropists and the international donors should be given strict monitoring by the local authority for proper and fair distribution or given out in accordance to the family configuration. Adequate restrooms should be provided to prevent a breakdown of epidemic disease as each IDP camps are densely populated about the land space on which tents were built. There should be a Police station or Police Post and standing army of ratio 1: 50 members of the IDP population in order not to prevent resurgent of the Boko Haram threat. A proper security check must be carried out on all visitors to the camp as Boko Haram's Stooge may penetrate the camps with explosives or suicide bombers. If all these could be provided, the IDP would leave meaningful life in the short time of their stay in temporary IDP camps.

\section{Conclusion}

The study has investigated the reason for insurgency in Nigeria, the effects of the terrorism on the displaced children in the IDP and terrorist captivity and solution to their future ambition. The general causes of IDP and the reason for terroristic acts by an individual or groups concerning the theoretical perspectives of pathological and personality concepts also were explored. The rights of the child and the African Union Convention for the Protection and Assistance of Internally Displaced Persons in Africa (Kampala Convention) shed more light on the knowledge. Other sub-topics are Boko Haram insurgency and the Children in IDP, International Humanitarian Agency's assessment of the challenges of the IDPs including the images of children with health challenges as a result of malnutrition experienced by children in the IDP camps in Nigeria. The statistics of IDP as a result of disaster and conflict on global scale was reported by UNHCR and Tables: 1 and 2 showed only the population figures of the IDP as a result of conflicts and disasters while Table: 3 concentrates on the local IDP camps and the population distribution in each of the camps across 13 states of 219 local government areas of the Northern States of Nigeria.

However, on the future ambition of the children, education can be seen as the only tool to streamline and lift the future of the displaced children out of their fragile and poor situation they found themselves presently, assisting them to overcome their mentally disturbed and psychologically traumatized state of being from deadly events they had already witnessed in the history of terroristic threats of the Boko Haram militants during attacks on their parents and siblings. If a lack of provisions 
INTERNATIONAL JOURNAL OF ACADEMIC RESEARCH IN BUSINESS AND SOCIAL SCIENCES Vol. 10, No. 2, Feb, 2020, E-ISSN: 2222-6990 @ 2020 HRMARS

for proper education delivery persists, that short-sightedness on the part of the government may irreversibly affect a sustainable development for the future of Nigeria in the long-run as the case of poor education and corruption not unique with Durumi IDP Camp alone, but cuts across the established IDP Camps. The sufferings of the children and other people at different stages of life in IDP are not unconnected to corruption in the public sector. It is a matter of fact that the UNHCR has been saddled with the responsibilities of taking proper care of the IDP but at the same time the humanitarian support from local authority at various levels posed a serious concern. Therefore, if facilitating decent life for IDPs is still a priority to the government, then, it is advisable that the government policy of using the service of the whistle-blowers to detect those officers who are sabotaging service delivery in the IDPs be extended to IDP camps and the management in charge so that they can live up to the task.

\section{References}

Abimbola, O. A. (2011). Between Maitatsine and Boko Haram: Islamic Fundamentalism and the Response of the Nigerian State. Africa Today, 57(4), 98-119.

All African. (2013). Nigeria: Boko Haram Attack on Yobe School - You'll Burn in Hell, Jonathan Tells Sect. Retrieved on 5 September, 2019 from http://allafrica.com/ stories/201307080649.html Alzgool, M. (2019). Nexus between Green HRM and Green Management towards Fostering Green Values. Management Science Letters, 9(12), 2073-2082.

AU Convention for the Protection and Assistance of Internally Displaced Persons in Africa. (2009) (Kampala Convention) adopted by the Special Summit of the African Union held in Kampala, Uganda on 22 October 2009 and entered into force on 6 December 2012.

Background Paper. (2006). First Regional Conference on Internal Displacement in West Africa. Background Paper Abuja, Nigeria 26-28 April 2006. Retrieved from 3 Jan 2017 https://www.brookings.edu/wpcontent/uploads/2012/04/ECOWAS_bgpaper_English.pdf

BBC. (2016). Colombia's Farc Rebels - 50 Years of Conflict. Retrieved on 2 June, 2019 from http://www.bbc.com/news/world-latin-america-36606568

BBC, Africa. (2017). Sudan Country Profile. http://www.bbc.com/news/world-africa14094995

Briney, A. (2017). The Geography of Nigeria. Retrieved on 18 October, 2018 from https://www.thoughtco.com/geography-of-nigeria-1435246

Cambridge Advanced Learner's Dictionary. (2008). Aggression. London, Cambridge: ArmandaCambridge University Press.

Jones, C. (2016). 8 sad pictures from Nigerian IDP camps. Retrieved from https://www.naij.com/947805-nigerian-idp-camps-8-pictures-will-move-tears.html

Cohen, R. (2005). UNHCR: expanding its role with IDPs. Retrieved on 10 March,2019 from https://www.brookings.edu/articles/unhcr-expanding-its-role-with-idps/

Equal Times. (2018). In north-eastern Nigeria, traffickers are preying on vulnerable children in IDP camps. Reported by Philip Obaji Jr. Retrieved on December 15, 2019 from https://www.equaltimes.org/in-norh-eastern-nigeria?lang=en\#.XI_vkPkzbIU

Human Rights Watch. (2016). Nigeria: Officials Abusing Displaced Women, Girls

Displaced by Boko Haram and Victims Twice Over. Retrieved on 15 June, 2017 from https://www.hrw.org/news/2016/10/31/nigeria-officials-abusing-displaced-women-girls 
INTERNATIONAL JOURNAL OF ACADEMIC RESEARCH IN BUSINESS AND SOCIAL SCIENCES Vol. 10, No. 2, Feb, 2020, E-ISSN: 2222-6990 @ 2020 HRMARS

IDCM. (2013-1019). An International History of Internal Displacement. Retrieved on 09 January, 2018 from https://www.internal-displacement.org/internal-displacement/history-of-internaldisplacement

IDCM (2014). Azerbaijan: After more than 20 years, IDPs still urgently need policies to support full integration. Retrieved 2 July, 2019 from http://www.internal-displacement.org/europe-thecaucasus-and-central-asia/azerbaijan/2014/azerbaijan-after-more-than-20-years-idps-stillurgently-need-policies-to-support-full-integration/

Kent, I., \& Nicholls, W. (1977). The psychodynamics of terrorism. Mental Health \& Society, 4,1-8.

Khalid, N., Islam, D. M. Z., \& Ahmed, M. R. M. (2019). Sentrepreneurial Training and Organizational Performance: Implications for Future. Humanities \& Social Sciences Reviews, 7(2), 590-593.

LoCicero, A., \& Sinclair, S. J. (2007). Terrorism and terrorist leaders: insights from developmental and ecological psychology. Studies in Conflict and Terrorism, 31, 227-250.

Maiangwa, B., and Amoo, O. B. (2015) Daughters, Brides, and Supporters of the Jihad": Revisiting the Gender-Based Atrocities of Boko Haram in Nigeria. African Renaissance Volume 12, Number 2, 2015 pp 117-144.

Maile, J., Walters, T. K., Ramírez, J. M., and Antonius, D. (n d.). Aggression in Terrorism. Chapter Two. Retrieved on 24 August, 2019 from http://eprints.ucm.es/9995/2/353_CSPChapter_02.pdf

Meloy, J. R. (2006). Empirical Basis and Forensic Application for Affective and Predatory Violence, Australia and New Zealand Journal of Psychiatry, 40: 539-547

Merriam Online Webster Dictionary. (2017). Definition of Aggression. Retrieved on 9 January, 2019 from https://www.merriam-webster.com/dictionary/aggression.

Muhammad, K., Saoula, O., Issa, M., \& Ahmed, U. (2019). Contract Management and Performance Characteristics: An Empirical and Managerial Implication for Indonesia. Management Science Letters, 9(8), 1289-1298.

National Bureau of Statistics. (2016). Unemployment/Under-employment Watch Q1. Retrieved on 3 February 2019 from www.nigerianstat.gov.ng/download/397

Oduwole, T. A., \& Fadeyi, A. O. (2013). Issues of Refugees and Displaced Persons in Nigeria. Journal of Sociological Research, 4(1).

Olusegun, O., Ogunfolu, A. (2019) "Protecting Internally Displaced Children in Armed Conflicts: Nigeria in Focus," Notre Dame Journal of International \& Comparative Law: 9(2), Article 4.

Osayimwen, E. (2017). How A Lack of Education Shatters the Dreams of Internally Displaced Children in Nigeria? Retrieved On 8 April, 2019 from https://peponi-project.com/2017/05/10/lack education-children-nigeria/

Marina, P. (2014) Theoretical Framework Internal Displaced People and Terrorism. Retrieved on 5 November, 2019 from https://www.opendemocracy.net/marina-petrova/can insurgency-bestamped-out-solely-by-military-means

Post, J. M. (1984). Notes on a psychodynamic theory of terrorist behavior. Terrorism: An International Journal, 7, 241-256.

Ruby, C. (2002). Are Terrorists Mentally Deranged? Analyses of Social Issues and Public Policy, 2, 1526.

Scott, A. (2004) Mishandling Suicide Terrorism. The Center for Strategic and International Studies and the Massachusetts Institute of Technology. The Washington Quarterly 27(3), 67-90. 
INTERNATIONAL JOURNAL OF ACADEMIC RESEARCH IN BUSINESS AND SOCIAL SCIENCES

Vol. 10, No. 2, Feb, 2020, E-ISSN: 2222-6990 @ 2020 HRMARS

Shuaibu, S. S., \& Salleh, M. A. (2016). Historical Evolution of Boko Haram in Nigeria: Causes and Solution. Proceedings of ICIC 2015 International Conference on Empowering Islamic Civilization in the 21st Century, 6-7 September 2015 - Universiti Sultan Zainal Abidin, Malaysia.

Silke, A. (1998). Cheshire-cat logic: The recurring theme of terrorist abnormality in psychological research. Psychology, Crime \& Law, 4(5), 1- 69.

Stanford, M., Houston, R., Villemarette-Pittman, N., \& Greve, K. (2003). Premeditated aggression: Clinical Assessment and Cognitive Psychophysiology. Personality and Individual Differences, 34, 773-781.

Strentz. (1981). The terrorist organizational profile: A psychological role model. In Alexander, Y. \& Gleason, J (Eds.). Behavioral and quantitative perspectives on terrorism (pp. 86-104). New York: Pergamon.

The Authority, (2017). The State of the IDP in Nigeria. Retrieved on 25 January, 2019 from http://www.authorityngr.com/2017/04/State-of-IDP-camps-in-Nigeria/

The Cambridge Advanced Learner's Dictionary. (2008) (third ed.) Insurgency. online version Cambridge: Cambridge University Press.

The Chicago Tribune. (2017). US Declaration of "Ethnic Cleansing" in Myanmar on way. Retrieved on 30 May, 2019 from http://www.chicagotribune.com/news/nationworld/ct-ethnic-cleansingmyanmar-20171024-story.htm

The Daily Trust. (2016). Nigeria's IDPs: A gloomy future without education.

AnneMarie McCarthy (Emergencies' Coordinator, Planned International Ireland). Retrieved from https://www.dailytrust.com.ng/news/ opinion/ nigerias-idps-a-gloomy-future-withouteducation/158644.html

The Nigerian Lawyer. (2017). Senior Lawyers know the Corrupt Judges, Says Falana

(SAN).

Retrieved on 21 April, 2019 from https://thenigerialawyer.com/senior-lawyers-knowcorrupt-judgessays-falana-san/

The Premium Times. (2016). Nigerian Army court-martials 20 soldiers for 'illicit arms sales, rights abuses.' Retrieved on 19 June 2018 from https://www.premiumtimesng.com /news/headlines/208381-Nigerian-army-court-martials-20-soldiers-illicit-arms-sales

rights-abuses.htm

The Vanguard, (2017). On the accidental bombing of IDP camp in Bornu. Retrieved on 20 October, 2019 from https://www.vanguardngr.com/2017/01/on-the-accidental-bombing-of-idpcamp-in-borno/

Umar, Sani. (2012). "The Popular Discourses of Salafi Radicalism and Salafi Counter-radicalism in Nigeria: A Case-study of Boko Haram. Journal of Religion in Africa, 42(2), 118-144.

UN-SPIDER -Office of Outer Space Affairs. (2017). Nigeria National Emergency Management Agency (NEMA). Retrieved on 14 August, 2018 from http://www.un-spider.org/links-andresources/ institutions/national-emergency-management-agency-nema

UNHCR. (1998) Guiding Principles on Internal Displacement ADM 1.1, PRL 12.1, PR00/98/109 (1998) (Guiding Principles. http://www.unhcr.org/news/press/2017/1/587f6a734/unhcrsgrandi-failures-behind-nigeria-idp-camp-tragedy-must-identified.html

(UNISEF) Fact Sheet: A summary of the rights under the Convention on the Rights of the Child. Retrieved from https://www.unicef.org/crc/files/Rights_overview.pdf 
INTERNATIONAL JOURNAL OF ACADEMIC RESEARCH IN BUSINESS AND SOCIAL SCIENCES

Vol. 10, No. 2, Feb, 2020, E-ISSN: 2222-6990 @ 2020 HRMARS

United Nations Office for the Coordination of Humanitarian Affairs (UNOCHA), 2nd Ed., (2004), Guiding Principles on Internal Displacement, Geneva: United Nations Publications, [Accessed Online: 22.01.2009], Retrieved on 2 April 2019 from World Wide Web http://www.brookings.edu/fp/projects/idp/resources/GPsEnglish.pdf

UNHCR, (1999). Internally Displaced Persons Resolution 1999/47 (56 $6^{\text {th }}$ Meeting) United Nations High Commissioner for Human Rights. Geneva, Switzerland. (C) Copyright 1996-2000.

UNHCR. (2001) History of UNHCR. Retrieved on 2 March 2017 from https://www.unhcr.org/enmy/history-of-unhcr.html

UNISEF and Partners. (2017). UNISEF Nigeria Humanitarian Situation Report No. 2 16-30 June 2017 pp1-6. Retrieved on20 December 2019 from https://reliefweb.int/sites/reliefweb.int/files/resources/UNICEF\%20Nigeria\%20 Humanitarian\%20Situation\%20Report\%20No.12\%2C\%2016-30\%20June\%202017.pdf

UNICEF. (2007). Children's rights and Journalism practice- a right-based perspective. Retrieved on 2 March, 2020 from https://www.unicef.org/honduras/UNICEF_Master_FEB_2008_BON

UNICEF. (2007). Information Sheet: the child 's rights Act. Retrieved on 3 March, 2020 from https://www.unicef.org/wcaro/WCARO_Nigeria_Factsheets_CRA.pdf

VOA. (Voice of America) (2017). Report: Corruption in Nigerian Military Benefits Boko Haram. Retrieved on 29 May, 2019 from https://www.voanews.com/a/corruption-nigeriamilitaryboko-haram-report/3862196.html

WHO. (2015) Nigeria: Statistics. Retrieved on 7 January 2019 from http://www.who.int/ countries/nga/en/ 